This PDF is a selection from an out-of-print volume from the National Bureau of Economic Research

Volume Title: Tax Policy and the Economy, Volume 14

Volume Author/Editor: James M. Poterba, editor

Volume Publisher: MIT Press

Volume ISBN: 0-262-66164-0

Volume URL: http://www.nber.org/books/pote00-2

Publication Date: January 2000

Chapter Title: Inter Vivos Transfers or Bequests? Estate Taxes and the Timing of Parental Giving

Chapter Author: Kathleen McGarry

Chapter URL: http://www.nber.org/chapters/c10848

Chapter pages in book: (p. 93 - 122) 


\section{Inter Vivos Transfers or Bequests? Estate Taxes and the Timing of Parental Giving}

\section{Kathleen McGarry}

University of California, Los Angeles and NBER

\section{EXECUTIVE SUMMARY}

The estates of individuals who die with wealth over specified levels are taxed at high marginal rates. In 1999 the marginal tax rates ranged from 37 percent on estates of $\$ 650,000$ to 55 percent on estates of over $\$ 3$ million. Because children are the most frequent heirs, one would expect other gift-giving behavior to children to be affected by the potential tax rates faced by the estate. However, surprisingly little is known about this relationship. This paper investigates the link between estate taxes and inter vivos transfers from parents to children. I find that the existence of estate taxes hastens the transfer of resources from parents to children. Those parents whose estates are likely to be subject to tax make greater inter vivos gifts to their children and these gifts increase with the marginal tax rate. I estimate that if estate taxes were eliminated, inter vivos transfers from parents to children would be reduced by nearly 30 percent per year. Despite these findings, there is also strong evidence that parents fail to take full advantage of opportunities for tax-free giving and transfer too little to children over their own lifetimes. 


\section{INTRODUCTION}

Recent proposals by the United States Congress have once again brought estate and gift taxes to the forefront in policymaking circles. While estate taxes affect relatively few decedents, they are the subject of much debate and have spawned an entire industry devoted to estate planning. Despite the public concern and the continued attention of policymakers, researchers have devoted little attention to the behavioral effects of estate taxes, and almost none to the relationship between these taxes and inter vivos giving. We have therefore been able to provide little insight into how these behaviors would change were there to be changes in the tax laws.

Estate and gift taxes alter the price of transferring resources to others. The estates of individuals who die with wealth above specified levels face high marginal tax rates. These taxes increase the cost of transferring wealth to heirs and may therefore make consumption and charitable giving more appealing options for the potential donor. Details of the estate- and gift-tax code also provide strong incentives for gifts to be made at certain times in the donor's life, and to be made to particular recipients. These incentives likely affect the well-being of both donors and recipients and may alter the total amount given over a lifetime. Finally, while estate and gift taxes obviously provide revenue to the government, the amount eventually collected from these taxes will depend on the responsiveness of individual gift-giving behavior to the incentives embodied in the tax code.

This paper examines the effects of estate taxes on inter vivos giving, with the focus on the transfer of resources from parents to children. ${ }^{1}$ I find that estate taxes hasten such transfers; higher estate taxes increase the cost of bequeathing wealth to heirs and thus increase the probability and amount of inter vivos transfers. Simulations demonstrate that the elimination of the estate tax would reduce yearly inter vivos transfers from the wealthy to their children by nearly 30 percent. I also point to evidence that many wealthy parents fail to take full advantage of opportunities to make tax-free transfers despite expected marginal tax rates on eventual estates of over 40 percent. Preliminary analysis of this behavior suggests that differences in expected length of life and in the desire to transfer to children may be partially responsible.

The next section outlines the provisions of the tax law, with special

1 Estate taxes likely affect other forms of economic behavior, including savings (Gale and Perozek, 1999), labor supply (Joulfaian and Wilhelm, 1994), and charitable giving (Boskin, 1976; Feldstein and Clotfelter, 1976; Joulfaian, 1991, 1998). 
attention paid to the incentives for inter vivos giving. Section 3 examines the relationship between giving and the holding of taxable levels of wealth, while section 4 focuses on the responsiveness of giving to changes in the marginal tax rate, and simulates changes in behavior in response to proposed changes in the tax law. Section 5 discusses the extent to which parents engage in optimal gift-giving behavior, and a final section concludes.

\section{OUTLINE OF ESTATE- AND GIFT-TAX PROVISIONS}

The taxing of financial transfers is governed by a complex set of provisions. There are a number of exemptions and special cases embodied in the law that affect the incentives to give. In this section I first provide an overview of the general principles involved and then discuss in more detail those factors that might affect the timing and amount of transfers to children.

\subsection{Main Features of the Tax Law}

Transfer taxes have been used at several times in U.S. history as a temporary revenue raising measure, especially in times of war (see Eller, 1996, for a discussion). The current system was instituted with the Tax Reform Act of 1976 and is based on a unified treatment of inter vivos gifts and bequests: the taxes owed by an estate are based on the total amount transferred by an individual, including gifts made during the decedent's life and those transferred as part of his estate.

There are, however, several important components of the system that effectively eliminate any such taxes for most individuals and significantly reduce the tax owed by others. First, there exists a unified tax credit that exempts all but the very largest transfers from tax. In 1999 the unified credit was $\$ 211,300$, which served to eliminate all taxes on transfers of up to $\$ 650,000$. Under current law this credit will gradually increase to $\$ 345,800$ in 2006 , permitting up to $\$ 1$ million to be transferred tax-free.

A second important component of the estate tax is the unlimited marital deduction. Bequests to a spouse, regardless of the amount, are untaxed. By taking advantage of the marital deduction and the unified credit a couple may currently transfer tax-free a total of $\$ 1.3$ million, if each gives $\$ 650,000$ to nonspouse heirs.

In addition to the unified tax credit and spousal deduction, a limited amount can be transferred in each year without counting against the lifetime $(\$ 650,000)$ exemption. The annual exclusion was $\$ 3,000$ per recipi- 
TABLE 1

Marginal Estate Tax Rates

\begin{tabular}{lcccc}
\hline Value of estate & Tax rate $(\%)$ & Value of estate & Tax rate $(\%)$ \\
\cline { 2 - 4 } \cline { 4 - 5 } $0-\$ 10,000$ & 18 & & $500,000-750,000$ & 37 \\
$10,000-20,000$ & 20 & & $750,000-1,000,000$ & 39 \\
$20,000-40,000$ & 22 & $1,000,000-1,250,000$ & 41 \\
$40,000-60,000$ & 24 & $1,250,000-1,500,000$ & 43 \\
$60,000-80,000$ & 26 & $1,500,000-2,000,000$ & 45 \\
$80,000-100,000$ & 28 & $2,000,000-2,500,000$ & 49 \\
$100,000-150,000$ & 30 & $2,500,000-3,000,000$ & 53 \\
$150,000-250,000$ & 32 & $3,000,000-10,000,000$ & 55 \\
$250,000-500,000$ & 34 & $10,000,000-21,040,000^{(a)}$ & 60 \\
& & $>21,040,000$ & 55 \\
\hline
\end{tabular}

Source: IRS $(1997,1999)$.

(a) Changed to $\$ 10$ million- $\$ 17,184,000$ in 1998.

ent in 1977, increased to $\$ 10,000$ in 1982 , and remains there currently. Beginning in 1999 this amount will be indexed for inflation. ${ }^{2}$

This exclusion provides a mechanism whereby wealthy individuals can spend down their estates, reducing the amount subject to tax. Because the $\$ 10,000$ limit is per donor and per recipient, families can potentially transfer a substantial sum in each year. A married couple with two children, each of whom is married with two children of his own, can transfer $\$ 160,000$ per year to their children's families without incurring gift taxes or impinging on the lifetime exemption. Extending such giving for a period of years can result in substantial spend-down. ${ }^{3}$

Finally, charitable bequests are deducted from the gross estate before calculating the tax owed. This provision significantly reduces the price of charitable giving. ${ }^{4}$

The marginal tax rates applicable to the combined total of inter vivos transfers and bequests are reported in Table 1 . The rates range from 18 percent for transfers of less than $\$ 10,000$ to 55 percent for transfers over $\$ 3$ million. With the current unified deduction, the lowest marginal rate

2 After adjusting for inflation the amount of the exclusion will be rounded down to the nearest $\$ 1000$, so that the effects of a moderate rate of inflation will not be felt immediately, nor will changes be likely to occur in every year.

${ }^{3}$ I know of no empirical study that has examined the actual patterns of transfers over time with regard to the potential tax implications.

4 Studies of the relationship between estate taxes and charitable giving have found a large response in the amount given to the marginal tax rate faced by the estate, with price elasticities of demand for charitable bequests of greater than 1.0 in absolute value (Boskin, 1976; Joulfaian, 1991; Auten and Joulfaian, 1996). 
actually faced by an estate is 37 percent. Estates between $\$ 10$ million and $\$ 21.04$ million face a marginal rate of 60 percent, offsetting the lower rates applied to smaller amounts. ${ }^{5}$

If wealthy families wish to reduce the number of times dynastic wealth is taxed, they might choose to make bequests that skip a generation, transferring resources directly to grandchildren and reducing the number of times the family fortune is taxed. To limit the ability of the wealthy to avoid estate taxes in this way, a generation-skipping tax was implemented in 1977. With this tax, transfers of over a given amount made directly to grandchildren (or others of that generation) are subject to an additional tax. ${ }^{6}$ Currently the exempt amount is $\$ 1$ million and the tax rate for amounts above this limit is 55 percent. ${ }^{7}$ This tax would be expected to discourage large transfers to subsequent generations, and in fact, a relatively small fraction of estates are liable for generationskipping taxes. Based on data from 1992 decedents, Joulfaian (1998) reports that less than one-half of one percent of estates filing tax returns owed generation-skipping taxes.

\subsection{Incentives for Inter Vivos Giving}

For parents who anticipate bequeathing large sums to their children (or other heirs), the $\$ 10,000$ annual exemption provides a strong incentive for inter vivos giving. ${ }^{8}$ There are, however, additional features of the tax law that might also affect the desired timing of gifts. As highlighted in Poterba (2000b) and Joulfaian (1999), while transfers beyond the $\$ 10,000$ limit are often preferable to bequests, the optimal strategy depends very much on the type of asset.

The overall preference for taxable inter vivos giving relative to bequests follows in part from the accounting principles used to determine the tax owed. Taxes on inter vivos gifts are calculated on top of the actual (net) amount transferred, while taxes on bequests are calculated on the

5 This interval was changed to $\$ 10$ million-\$17,184,000 for those dying in 1998 or later (Internal Revenue Service, 1999). I report the values for earlier years in Table 1 because they were the applicable rates in the years to which the data pertain.

${ }^{6}$ No generation-skipping tax is applied if the parents of the grandchild are deceased so that the skip in generations is made out of necessity and not as a means of tax avoidance.

7 This exempt amount will be indexed for inflation beginning in 1999, with amount rounded down to the nearest $\$ 10,000$.

${ }^{8}$ Throughout this paper I assume that individuals receive utility from their own consumption and from transfers to heirs, but not from taxes paid to the government. The desire to give to heirs can come about because the future decedent cares about the well-being of his heirs (altruism), because he wishes to use the transfer to purchase particular behaviors from the recipient (exchange), or because he receives utility directly from making the transfer (warm glow). 
entire estate and subtracted from the (gross) amount bequeathed. Consider a parent who is certain to leave an estate that will be subject to tax at a marginal rate of 55 percent. Suppose the parent transfers an additional $\$ 10,000$ as an inter vivos gift; the tax owed is $0.55 \times \$ 10,000=$ $\$ 5,500$ which comes out of the parent's other resources. Transferring $\$ 10,000$ therefore costs the parent $\$ 15,500$, for an effective tax rate of 0.35 . If the same amount $(\$ 10,000+\$ 5,500)$ were transferred as a bequest and taxed at a rate of 55 percent, the taxed owed would be $0.55 \times$ $\$ 15,500$ or $\$ 8,525$, and the beneficiary would receive $\$ 15,500-\$ 8,525=$ $\$ 6,975$, considerably less than if the $\$ 15,500$ amount were used to finance a gift.

Prior to the indexing of the exempt amount in 1999, inter vivos transfers also had an advantage over bequests in that since they were made earlier, a greater real value could be transferred (i.e., $\$ 10,000$ transferred in 1985 was worth more than $\$ 10,000$ transferred in 1995). Finally, if assets grow in real terms, taxable inter vivos giving is preferred to taxable bequests. For example, if the balance of a savings account, valued at $\$ 20,000$ in 1985 , is transferred in that year, the taxable portion of the gift is $\$ 10,000$. If the entire $\$ 20,000$ is left untouched by the recipient in an account earning an annual 5-percent real rate of return, it will grow to $\$ 24,380$ by 1995 . If the same amount accumulated interest at the same rate but were held by the donor and transferred in 1995, the taxable portion of the gift would be $\$ 14,380$ and the tax owed would be greater than that paid with the earlier transfer.

These aspects of the law seem to indicate unambiguously that transfers should be made as early as possible. However, for some assets the advantages are less clear.

The treatment of capital gains differs for inter vivos transfers and bequests. If assets which have accrued capital gains are transferred at death, the value of the asset is "stepped up" so that the recipient's basis for the calculation of future capital gains taxes is the value at the time of receipt. No capital gains taxes are paid on the gains accrued during the original owner's life. Conversely, if such assets are transferred as inter vivos gifts, the basis is not stepped up, and the original owner's basis is carried over to the recipient. When the asset is eventually sold, the recipient must pay taxes on all capital gains as calculated from the basis of the original owner. This regulation lowers the price of a bequest for assets with unrealized capital gains.

Family farms and businesses also benefit taxwise in several important ways. First, if a farm or business is bequeathed, the value of the real property contained in the transfer can be based on its worth as part of 
the ongoing concern. ${ }^{9}$ Thus, a family farm that is potentially more valuable in other use is taxable only up to its value as a farm, provided the heirs continue to operate it as such. Second, taxes owed on the transfer of a farm or business can be spread out over 14 years, providing additional tax relief for heirs. ${ }^{10}$ Finally, the Taxpayer Relief Act of 1997 provides an additional exemption of up to $\$ 675,000$ for family businesses with qualifications similar to the requirements for the special valuation. These factors lessen the cost of bequests relative to inter vivos transfers. It is possible to transfer a small number of shares in a business over time and value them at less than the corresponding fraction of the business's net worth if they represent minority positions in the concern. The arguments in this case are that an individual actually purchasing a small block of stock in a closely held business would have little control over the operation of the concern relative to other stockholders, as well as difficulty reselling the shares, and the share price would need to be discounted accordingly. Transferring shares of a family business this way thus provides an advantage over the use of a bequest wherein the business would be transferred in its entirety. Likewise, a large block of stock in a publicly owned firm, transferred at a single point in time (say at the death of the owner), may be devalued relative to the market price if it is thought that the share price would suffer were the recipient to sell the block all at once on the open market. Using this method, the total tax bill might be lessened by transferring the stock as a bequest. Cooper (1979) provides several fascinating examples of individuals who have used these methods and others to dramatically reduce the tax owed on transfers.

\section{TAXABLE WEALTH AND INTER VIVOS GIVING}

These various incentives embodied in the estate and gift tax make it difficult to predict the best strategy for an individual seeking to maximize the amount transferred to heirs. However, it is reasonable to presume that those facing eventual estate taxes would first choose to make tax-free inter vivos gifts of $\$ 10,000$, and a significant fraction of this popu-

\footnotetext{
9 Among other limitations, the reduction in the value of the estate due to this special valuation is limited to $\$ 750,000$. This amount is indexed for inflation beginning in 1999 .

10 Payment of tax, but not interest charges, may be deferred entirely for up to 5 years, after which time the total must be paid within ten years. The interest rate charged on taxes owed is significantly below the market rate of interest. Joulfaian (1999) finds that this deferment plays a substantial role in increasing the desirability of bequests relative to inter vivos transfers.
} 
lation would make at least some gifts beyond that level. Moreover, the propensity to make inter vivos transfers will vary with the types of assets constituting bequeathable wealth. ${ }^{11}$

Using data from the 1995 Survey of Consumer Finances (SCF), Poterba (2000b) finds a marked increase, both in the probability of making any transfer and in the probability of making transfers totaling $\$ 10,000$ or more, as wealth crosses the $\$ 600,000$ threshold (the value of exempt bequests in the year to which his data pertain). ${ }^{12}$ His results are reproduced in Table 2, along with comparable figures from the Health and Retirement Study (HRS) and the Asset and Health Dynamics Study (AHEAD). ${ }^{13}$ For those aged 65-74 in the SCF, the probability of making any transfer to a child increases from 11.5 percent for those with net worth below $\$ 600,000$ to 29.5 percent for those with net worth in the range $\$ 600,000$ to $\$ 1.2$ million. The probability of a transfer of at least $\$ 10,000$ increases from 1.2 to 9.9 percent with this change in wealth. As shown in the second panel of Table 2, the HRS and AHEAD data yield higher probabilities of giving overall, but similar increases with taxable wealth. ${ }^{14}$ For those aged $65-74$ the probability of any transfer increases from 25.7 to 56.8 percent as one crosses from nontaxable to taxable levels of wealth, the probability of transferring $\$ 10,000$ or more increases from 3.0 to 17.9 percent for this same age group.

Those with bequeathable wealth above and below the taxable limits obviously differ in respects other than the probability of facing estate taxes, most notably, in their financial ability to make transfers. To control for income, wealth, and other factors that may differ across groups,

11 Because farms and businesses are illiquid, it may be more difficult or costly to make inter vivos transfers of these assets, and individuals with a large fraction of their portfolios tied up in such enterprises may be less likely to make such gifts than others with similar wealth, despite the potential tax advantages of doing so. This issue will be explored in the empirical work to follow.

12 The SCF is nearly ideal for studying the effect of estate taxes on behavior. In addition to a nationally representative sample of households, it contains an oversample of highincome and high-wealth households. The drawback of these data is that there is little information on the (potential) recipients.

13 The HRS and AHEAD are nationally representative samples of individuals born in the years 1931-1941 (HRS), and in 1921 or before (AHEAD). Interviews were conducted in 1992 and 1993, respectively, when respondents were 51-61 years old, or 70 and over. The surveys ask nearly identical questions and can easily be combined into a single sample. They contain a great deal of information on the income and assets of the respondents, as well as unusually detailed information about their children. The limitation of these data is that the sample sizes in the upper tails of the wealth distribution are small.

14. The HRS and AHEAD specifically ask parents about transfers made to children in the past year, and by doing so capture many more such gifts than the SCF, which asks a general question about transfers made to individuals outside the household. 
TABLE 2

Transfer Probabilities by Age and Wealth: SCF and HRS/AHEAD

\begin{tabular}{|c|c|c|c|c|}
\hline \multirow[b]{2}{*}{ Age category } & \multicolumn{4}{|c|}{ Probability of transfer (\%) } \\
\hline & $\begin{array}{l}\text { Wealth } \\
<600,000\end{array}$ & $\begin{array}{c}600,000- \\
1.2 \text { million }\end{array}$ & $\begin{array}{l}1.2-2.4 \\
\text { million }\end{array}$ & $\begin{array}{c}>2.4 \\
\text { million }\end{array}$ \\
\hline \multicolumn{5}{|c|}{ Survey of Consumer Finances } \\
\hline \multicolumn{5}{|l|}{ Any transfer } \\
\hline $55-64$ & $\begin{array}{l}13.1 \\
(1.6)\end{array}$ & $\begin{array}{l}18.7 \\
(6.4)\end{array}$ & $\begin{array}{c}27.6 \\
(10.1)\end{array}$ & $\begin{array}{c}39.0 \\
(10.9)\end{array}$ \\
\hline $65-74$ & $\begin{array}{l}11.5 \\
(1.6)\end{array}$ & $\begin{array}{l}29.5 \\
(6.9)\end{array}$ & $\begin{array}{c}22.2 \\
(10.4)\end{array}$ & $\begin{array}{c}44.6 \\
(10.7)\end{array}$ \\
\hline$>74$ & $\begin{array}{l}9.4 \\
(1.9)\end{array}$ & $\begin{array}{l}11.9 \\
(8.1)\end{array}$ & $\begin{array}{c}9.2 \\
(17.6)\end{array}$ & $\begin{array}{c}48.8 \\
(15.7)\end{array}$ \\
\hline \multicolumn{5}{|l|}{$>\$ 10,000$} \\
\hline $55-64$ & $\begin{array}{c}1.7 \\
(0.6)\end{array}$ & $\begin{array}{l}5.4 \\
(2.3)\end{array}$ & $\begin{array}{c}8.9 \\
(3.4)\end{array}$ & $\begin{array}{c}24.2 \\
(4.0)\end{array}$ \\
\hline $65-74$ & $\begin{array}{c}1.2 \\
(0.6)\end{array}$ & $\begin{array}{c}9.9 \\
(2.5)\end{array}$ & $\begin{array}{l}15.1 \\
(3.8)\end{array}$ & $\begin{array}{l}36.6 \\
(4.1)\end{array}$ \\
\hline$>74$ & $\begin{array}{c}1.4 \\
(0.7)\end{array}$ & $\begin{array}{l}9.6 \\
(3.0)\end{array}$ & $\begin{array}{l}8.7 \\
(6.6)\end{array}$ & $\begin{array}{l}38.3 \\
(5.9)\end{array}$ \\
\hline
\end{tabular}

Combined HRS/AHEAD surveys

Any transfer

\begin{tabular}{lcccc}
$55-64$ & 34.2 & 51.7 & 55.9 & 61.7 \\
& $(0.8)$ & $(2.8)$ & $(4.6)$ & $(7.7)$ \\
$65-74$ & 25.7 & 56.8 & 42.1 & 72.7 \\
& $(0.9)$ & $(4.2)$ & $(7.6)$ & $(13.4)$ \\
$>74$ & 21.2 & 50.7 & 63.4 & 85.4 \\
& $(0.8)$ & $(4.6)$ & $(9.6)$ & $(10.6)$ \\
$>\$ 10,000$ & & & & \\
$55-64$ & & & & \\
& 2.7 & 17.2 & 17.8 & 24.1 \\
$65-74$ & $(0.3)$ & $(2.1)$ & $(3.5)$ & $(6.8)$ \\
& 3.0 & 17.9 & 7.8 & 40.7 \\
$>74$ & $(0.3)$ & $(3.4)$ & $(4.4)$ & $(15.5)$ \\
& 2.4 & 16.5 & 18.7 & 36.8 \\
& $(0.3)$ & $(3.6)$ & $(8.1)$ & $(15.2)$ \\
\hline
\end{tabular}

Sources: SCF results from Poberta (2000b); HRS/AHEAD results, author's calculations. HRS/AHEAD samples are limited to families with children.

Definitions of wealth differ slightly across surveys. 
TABLE 3

Probit and Tobit Estimates for the Probability and Amount of Transfers: HRS/AHEAD

\begin{tabular}{|c|c|c|c|c|c|}
\hline & \multicolumn{3}{|c|}{ Probability } & \multicolumn{2}{|c|}{ Amount } \\
\hline & Coeff. & SE & Deriv. & Coeff. & SE \\
\hline \multicolumn{6}{|l|}{ Household wealth: } \\
\hline Lowest quartile & -0.478 & 0.048 & -0.157 & -6687 & 698 \\
\hline 2nd quartile & -0.277 & 0.042 & -0.091 & -4100 & 594 \\
\hline 3rd quartile & -0.132 & 0.037 & -0.043 & -2109 & 523 \\
\hline Highest quartile (omitted) & - & - & - & 一 & - \\
\hline Taxable estate & 0.611 & 0.186 & 0.201 & 9037 & 2384 \\
\hline $\begin{array}{l}\text { Taxable estate } \times \text { life } \\
\text { expectancy } / 10\end{array}$ & -0.122 & 0.046 & -0.040 & -1038 & 583 \\
\hline Life expectancy $/ 10$ & -0.015 & 0.013 & -0.005 & 471 & 194 \\
\hline Business wealth $(\$ 10,000 \mathrm{~s})$ & -0.000 & 0.001 & -0.000 & 20 & 8. \\
\hline Farm wealth $(\$ 10,000 s)$ & -0.013 & 0.004 & -0.004 & -189 & 54 \\
\hline Number of observations & \multicolumn{3}{|c|}{11,600} & \multicolumn{2}{|c|}{11,422} \\
\hline Mean of dependent variable & \multicolumn{3}{|c|}{0.30} & \multicolumn{2}{|c|}{1518} \\
\hline
\end{tabular}

Source: McGarry (2000, Table 3).

Parental characteristics included in the regressions but not shown are: married, number of children and grandchildren, income, race, schooling, poor health, mean children's income and schooling, variation in children's income and schooling.

Probability estimated with a probit model, amount estimated with a tobit.

Sample size differs across equations due to missing values on the amount.

McGarry (2000) estimates a probit model for the probability of giving. Included in the specification are the income and wealth of the parent, parental life expectancy, financial status of children, and several other variables. The results are reproduced in Table 3 . Even with these control variables, the indicator of a taxable estate has a sizable effect, predicting a 20-percentage-point increase in giving. ${ }^{15}$ Parents who have longer expected lives need to finance their own consumption for a greater number of years and, holding income and wealth constant, will be less likely to dispose of assets. The estimates of the model support this idea: The effect of having a taxable estate is reduced by length of life. An additional 10 years of life expectancy reduces the probability of making a transfer by 4 percentage points. Based on these estimates, an individual with a taxable estate and 10 years to live has a 16-percentage-point (or 50percent) greater probability of making a transfer than someone in the same wealth quartile but with an asset level below the taxable limit.

${ }^{15}$ A family is assumed to have a taxable estate if assets are greater than $\$ 600,000$ per spouse. 
In addition to affecting the probability of a transfer, the existence of an estate tax likely also affects the amount the donor transfers. In the HRSAHEAD sample, among those making positive inter vivos transfers, those with taxable bequeathable wealth transferred an average of $\$ 14,828$, while the less wealthy transferred only $\$ 5,588$ (not shown). The second pair of columns in Table 3 reports the effect a taxable estate has on the amount given in a tobit specification. Even when observable characteristics of the potential donor are controlled for, there remains a large and significant increase in transfers for those with a taxable estate, increasing the amount of the transfer by over $\$ 9,000$, and the effect is mitigated by length of life. ${ }^{16}$

The discussion in section 1.2 notes that the composition of the parent's portfolio will affect the price of inter vivos transfers relative to bequests. The tax treatment of farms decreases the costs associated with their transfer as a bequest, so a substantial fraction of wealth invested in a family farm ought to reduce the probability of an inter vivos gift. In contrast, the ability to transfer shares of a business at below-market rates will make inter vivos transfers of such assets more appealing. Assets that contain significant capital gains will benefit from a step up of the basis if transferred as a bequest, and the holding of a large amount of wealth in such assets may therefore reduce inter vivos transfers. At the same time, resources held in these various assets may be more or less liquid than others, affecting the ease with which parents can make transfers.

Poterba (2000b) explores these relationships and finds some evidence of differences in behavior associated with the types of assets held. The results, reported in Table 4, indicate that both the probability of making any gift, and the probability of transferring $\$ 10,000$ or more per child, are greater among those with a substantial fraction of their wealth in financial assets, and lower for those whose wealth is held in a home, although this latter effect is not significantly different from zero. The direction of the effect of business wealth differs across equations but is not significantly different from zero. When examining the potential role played by unrealized capital gains, Poterba finds that the greater the basis value of assets relative to their current market value (the smaller any unrealized gains), the lower the probability of making a transfer, although the effect is not significantly different from zero. This result is in contrast to what a tax-minimizing strategy would predict. However, for transfers above $\$ 10,000$ (those more likely to be made in the interest

16 Despite the controls for financial resources that are used in these regressions, it remains likely that some portion of the observed increase in transfers for those with taxable estates is simply a wealth effect. I discuss this possibility further in section 4.1. 
TABLE 4

Probit Estimates for the Probability of a Transfer: Survey of Consumer Finances

\begin{tabular}{|c|c|c|c|c|}
\hline & \multicolumn{2}{|c|}{ Any Transfer } & \multicolumn{2}{|c|}{$>\$ 10,000 /$ child } \\
\hline & Coeff. & Std. Err. & Coeff. & Std. Err. \\
\hline \multicolumn{5}{|l|}{ Household wealth: } \\
\hline $\begin{array}{l}\text { Net worth }<600,000 \\
\quad \text { (omitted category) }\end{array}$ & 一 & - & 一 & - \\
\hline $\begin{array}{l}\text { Net worth } 600,000-1.2 \mathrm{mil}- \\
\text { lion }\end{array}$ & 0.270 & 0.137 & 0.138 & 0.233 \\
\hline $\begin{array}{l}\text { Net worth } 1.2 \text { million-2.4 } \\
\text { million }\end{array}$ & 0.287 & 0.147 & 0.561 & 0.277 \\
\hline Net worth $>2.4$ million & 0.804 & 0.129 & 1.257 & 0.219 \\
\hline Age of younger spouse & -0.0003 & 0.0021 & 0.009 & 0.006 \\
\hline Married & -0.019 & 0.073 & -0.108 & 0.210 \\
\hline $\begin{array}{l}\text { Wealth share of financial } \\
\text { assets (millions) }\end{array}$ & 0.027 & 0.012 & 0.019 & 0.008 \\
\hline Wealth share in home equity & -0.022 & 0.021 & -0.007 & 0.030 \\
\hline Wealth share in business & -0.141 & 0.176 & 0.232 & 0.393 \\
\hline $\begin{array}{l}\text { Ratio of basis to market value } \\
\text { of assets }\end{array}$ & -0.219 & 0.105 & 0.192 & 0.075 \\
\hline $\begin{array}{l}\text { Number of Observations } \\
\text { Log likelihood }\end{array}$ & \multicolumn{2}{|c|}{$\begin{array}{c}3394 \\
-1348.21\end{array}$} & \multicolumn{2}{|c|}{$-137.56^{3394}$} \\
\hline
\end{tabular}

Source: Poterba (2000b, Table 9).

of estate planning), the direction of the effect is as expected. McGarry also finds no difference in transfer probabilities with respect to business wealth, but significantly lower probabilities for those with substantial farm wealth.

\section{RESPONSIVENESS TO TAX RATES}

Over time there have been numerous changes in the laws pertaining to transfer taxes, and patterns of giving have varied in response. Joulfaian (1998) highlights some of these relationships. Perhaps the starkest change illustrated by Joulfaian is that stemming from the Tax Reform Act of 1976. This act unified the estate and gift taxes, resulting in a sharp jump in the gift tax beginning in 1977. Potential donors, learning of this change in 1976, immediately increased their gift giving behavior to make transfers at the lower rate. Taxes on 1976 transfers were due in 1977, and Treasury receipts in 1977 testify to the surge in giving in the previous year. Prior to 1977 , taxes paid on inter vivos gifts consistently 
amounted to approximately 8 percent of total transfer taxes collected. With the tax-induced spike in inter vivos gift giving, the share of transfer-tax receipts coming from gifts increased to 24 percent in 1977, along with an increase in total receipts, before falling to 3 percent in the subsequent year (Joulfaian, 1998, Table 17). Joulfaian also notes similar, although less dramatic, responses to legislative changes in the 1930s and 1940s.

One would expect these time-series patterns to be evident in crosssection analyses as well; those facing higher tax rates ought to behave differently from those facing lower rates. The continual increase in the likelihood of a transfer with the wealth of the parent observed in Table 2 is consistent with this prediction. In this section I control directly for the marginal tax rate the estate would face were the parent(s) to die on the date the data were collected. I estimate the responsiveness of inter vivos giving to changes in this tax rate and forecast the effect on transfer behavior of alternative proposals to modify the estate tax.

\subsection{Baseline Specification}

I examine transfer behavior in two steps. First, I estimate the probability of making a transfer to at least one child using a probit specification. In the second step I select only those parents who made a positive transfer and estimate the amount of the transfer as a function of the same set of regressors using ordinary least squares (OLS). This two-step procedure is preferable to a tobit model in that it provides more flexibility for the explanatory variables to affect the probability and the amount of the transfer differentially.

The explanatory variables in these equations include the income, wealth, ${ }^{17}$ and life expectancy of the parent (or parent couple), ${ }^{18}$ and the

17 In addition to the standard components of net worth, the measure of bequeathable wealth used here also includes the face value of life insurance policies and the value of balances in defined-contribution pension plans. It is difficult to know how to incorporate correctly the value of life insurance. The value of policies owned by the decedent (i.e., premiums paid by the decedent) are considered to be part of the estate. However, policies on the decedent's life held by the beneficiaries (or others) are not included. In these data I do not know who pays the premiums on the insurance policy. I assume that affirmative answers to the question "Do you have any life insurance?" indicates a policy he himself holds. I include the value of all policies held as of the interview date, including both whole life and term life policies. This assumption implies that the value of bequeathable wealth used here is likely an upper bound on the taxable amount. The conclusions of the paper are not sensitive to this decision.

${ }^{18}$ Life expectancy is from United States Department of Health and Human Services (1996). For married couples this is the sum of the life expectancies of the two spouses, since it is the total number of person-years over which the couple must finance consumption, and can make estate-reducing transfers, that will affect giving. 
average age and income of the children. ${ }^{19} \mathrm{I}$ use three variables to measure the effect of estate taxes on inter vivos giving: a $0-1$ indicator of whether the estate would be subject to tax, the marginal tax rate, and the interaction of the marginal tax rate with the expected lifespan of the parent(s). This specification allows for a discontinuity in giving as the marginal tax rate changes from zero for those with assets below the exempt amount, to 0.37 for those above. I limit my sample to respondents with living children. Table 10 in the appendix reports the summary statistics for the variables used in this analysis. With $\$ 600,000$ per spouse as an indicator of a taxable estate, 4.1 percent of the sample would be required to file an estate tax return were they to die at the interview date. ${ }^{20}$ Thirty-two percent of the sample made a transfer to at least one child in the past year.

\subsubsection{Probability of a Transfer The estimates of the probit model are} reported in Table 5. Both the income and wealth of the parent are positively and significantly related to the probability of making a transfer.

Assessing the impact of estate taxes is complicated and requires that one combine the three relevant terms in the equation-the indicator of a taxable estate, the marginal tax rate, and the interaction of the tax rate with life expectancy. For someone with a life expectancy of 5 years and assets just at the taxable limit (so that the marginal tax rate is 0.37 ), the effect of the estate tax is to increase the probability of a transfer by 6.4 percentage points $(-0.006+0.215 \times 0.37-0.005 \times 0.37 \times 5)$ relative to the probability with no tax. This change is equal to 21 percent of the

${ }^{19}$ I use logged values of the dollar-denominated variables of income, wealth, average income of children, and value of transfers. For some individuals in the sample, wealth is zero or negative. I use a splinelike transformation to deal with the nonpositive values. I include a dummy variable indicating zero wealth, and for negative wealth I use $-\ln (-$ wealth). I treat income similarly, including a dummy variable that is equal to one if the respondent reports zero income. (Negative income is not possible.)

${ }^{20}$ This sample obviously differs from the population that will eventually file estate taxes. Official estimates place the fraction of the decedent population filing estate tax returns at 2.8 percent (Eller, 1996). Estate tax returns are filed if the gross estate is above the limits even if the estate eventually owes no tax. Only about half of filers actually do owe taxes. The HRS/AHEAD data come from living respondents, so the measure of bequeathable wealth used here is only a proxy for the size of the eventual estate. Many individuals are currently employed and will likely accumulate more wealth over their lifetimes, leaving estates that are subject to tax. Others will dissave sufficiently, either through their own consumption or through tax-free gifts and charitable donations, that they will avoid all estate taxes. One might expect a higher fraction with taxable estates in these data than among recent decedents because these cohorts have greater lifetime income than their predecessors and ceteris paribus will have a higher probability of dying with estates valued at more than $\$ 600,000$, although increases in longevity will likely offset some of this difference. 


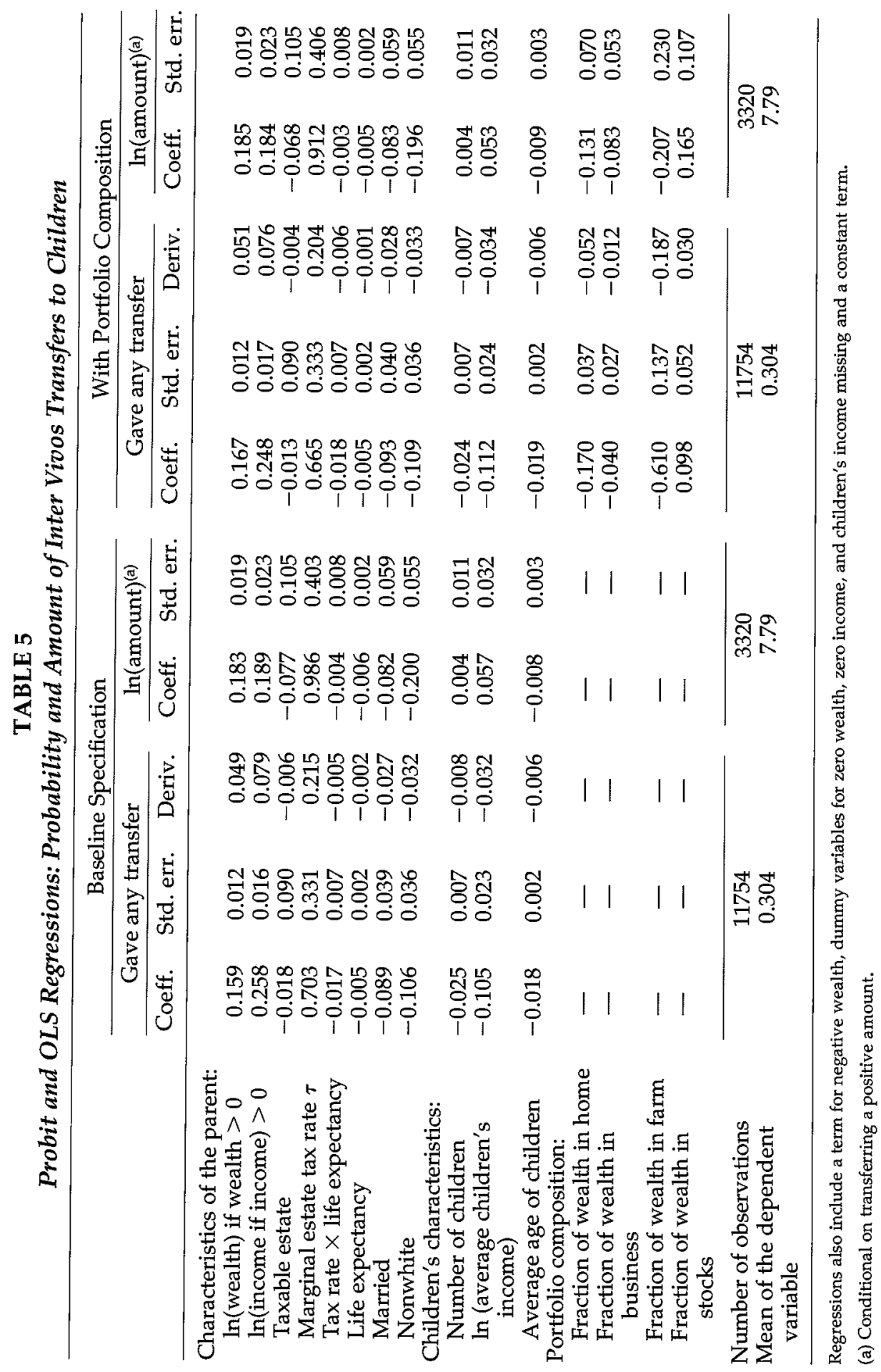


average (unweighted) probability. ${ }^{21}$ The probability of a transfer increases further as the marginal tax rate increases, and the change is significantly reduced with increasing length of life. For an individual with the same life expectancy but facing a marginal tax rate of 0.55 , the increase in the probability due to the estate tax alone (and not the underlying increase in wealth) is 9.9 percentage points, or 32.4 percent.

Transfers also depend significantly on the characteristics of the children. A higher average income indicates that children are relatively better off financially, and the probability of a transfer is less. ${ }^{22}$ Older children are less likely to be liquidity-constrained than younger children, and, consistent with this observation, the age of the children is negatively related to the probability of a transfer (Cox, 1990).

4.1.2 Amount of the Transfer To estimate the effect of taxes on the amount of the transfer, I limit the sample to the 3,320 families making a positive transfer; the predicted value is thus the conditional expectation. The average amount given by these families was $\$ 5622$. The second set of columns in Table 5 presents the results of a linear regression model with the left-side variable being the natural log of the amount.

As was the case for the probability of a transfer, both the income and wealth of the parent are positively related to the expected amount. A 10percent increase in parental wealth increases the amount of the transfer by 2 percent, and the effect of an increase in income is similar.

One of the drawbacks of the HRS-AHEAD data is the small number of very wealthy persons. By reducing the sample to those who make a positive transfer, the number facing nonzero marginal tax rates is further limited, and identification of the three tax variables will likely be less precise than one might desire. Despite this qualification, estate taxes continue to have some effect. For an individual in the 37-percent tax bracket with a life expectancy of 5 years, the expected amount of the transfer (conditional on its being positive) is 28 percent higher $(-0.077+$ $0.986 \times 0.37-0.004 \times 0.37 \times 5$ ) due to the estate tax. Again the effect increases with the tax rate, so that an individual with the same life expectancy and facing a marginal tax rate of 0.55 has an expected amount that is 45 percent higher than in the absence of estate taxes.

4.1.3 Tax Rates and Wealth Because the marginal tax rate facing the estate is directly related to parental wealth, the two variables are highly

${ }^{21}$ The mean of the left-side variable is 0.304 . It differs from the proportion making a transfer as reported above because the regressions are unweighted.

22 See McGarry (1999) for a more detailed analysis of the role of the income of children. 
collinear. This relationship makes it impossible to separate the effect of changes in tax rates from nonlinear changes in wealth. ${ }^{23} \mathrm{~A}$ portion of the increased probability and amounts given by those in higher tax brackets likely stems from increases in wealth not captured by the log specification, and the estimate effects are therefore best viewed as upper bounds on the role of estate taxes in driving behavior. ${ }^{24}$

\subsection{Portfolio Composition}

These equations treat all types of assets equally. However, as discussed earlier, it is likely that the type of assets held by parents affects their giftgiving behavior. The greater the capital gains tied up in an asset, the less costly it is to transfer the asset as a bequest, and the special tax treatment afforded family businesses at death has a similar effect. In contrast, other tax incentives associated with the transfer of farms or businesses may tilt the decision towards inter vivos transfers. Finally, issues of liquidity may make it difficult to transfer portions of family farms, businesses, or homes during the parent's life, resulting in a greater tendency to bequest wealth in these forms. In these data I have no way of measuring capital gains, but I am able to distinguish between wealth held in various forms. ${ }^{25}$ To control for these factors I add four variables to the above specifications: the fraction of wealth in a farm, a business, a home, and in stocks. The rightmost set of columns in Table 5 report the results.

The greater the fraction of wealth in a farm or a home, the significantly lower the probability of a transfer, while the greater the fraction of wealth in stock, the higher the probability. An increase in the fraction of wealth in a business decreases the probability of a transfer, but the effect is not significantly different from zero.

In the equation for the amount of the transfer, the effects are of the same sign, but only the fraction of wealth held in a home has a significant effect. The effect of farm wealth is large and negative but is estimated very

${ }^{23}$ Empirically the coefficient estimates for the tax rate and the taxable-estate dummy variable change noticeably when alternative measures of wealth are used in the regressions. However, the simulated effects of changes in amounts given (reported in Table 6) are quite similar to those obtained with the log specification.

${ }^{24}$ One way to attempt to separate the effects is to find alternative sources of variation in tax rates. Because states can impose their own estate, gift, or inheritance taxes, there exists the potential to identify the effects. Unfortunately for the analyst, the effect of state taxes in the vast majority of states is to reduce the revenue going to the federal government with no additional tax burden placed on the individual estates. In 1999 only four states had estate taxes that affected the taxes owed by the estate. Page (1997) uses the cross-state variation in estate taxes in 1983 data to attempt to separate the two effects. He finds that the minal estate-tax rate has a significant effect on the probability and amount of the transfer.

25 Note that the additional exclusion for family-owned businesses was not in effect at the time at which these data were collected. 
imprecisely, likely because of the small number of observations with nonzero farm wealth. In neither equation is there a significant change in the estimated effects of the marginal tax rates with the inclusion of these variables. ${ }^{26}$

\subsection{Simulations}

The equations estimated above provide a particularly useful framework for analyzing the responsiveness of transfers to changes in the tax law. The probit and OLS equations can be used separately to calculate the expected change in the probability of a transfer and in the conditional amount, and they can be combined to calculate an unconditional change in the amount given. In the simulations that follow I first calculate the predicted probability of making a transfer for each parent or parent couple and then calculate the expected amount conditional on a transfer being made. ${ }^{27}$ Using these two values, the unconditional expectation is calculated as

$$
E\left[t_{k}\right]=P\left(t_{k}>0\right) \cdot E\left[t_{k} \mid t_{k}>0\right]+P\left(t_{k}=0\right) \cdot 0
$$

for each family in the sample. The average of these expectations gives the average expected transfer over all individuals, and the sum yields the total expected transfers for this population. I repeat this procedure using the original estimates of the coefficients, but substituting alternative values of the effective marginal tax rate. ${ }^{28}$

Under current law the lifetime exemption will gradually increase from the $\$ 600,000$ applicable when these data were collected to $\$ 1$ million in 2006. A \$1-million exemption would decrease the fraction of the sample with taxable levels of assets from 4.1 to 1.6 percent, but would not change the marginal rate for those still subject to tax. Because the majority of the population does not face estate taxes even with the $\$ 600,000$ limit, raising it to $\$ 1$ million has no effect on their behavior. To focus on those actually experiencing a change in the tax environment, I report the simulated effects of the subsample with wealth above $\$ 600,000$ per

${ }_{26}$ The weakness of these results is not surprising. Data from 1992 decedents show that only 1.1 percent of estates owing tax used the special valuation applicable to family farms or business (Eller, 1996). It is therefore likely that much of the effect of the compositional variables is due to differences in the liquidity of assets.

27 Here I use the estimates from the equations without the compositional effects, although the results are similar if the latter specification is used.

28 The marginal effect of a change in the tax rate $\tau$ on the expected amount given can be calculated as

$$
\frac{\partial E\left[t_{k}\right]}{\partial \tau}=P\left(t_{k}>0\right) \cdot \frac{\partial E\left[t_{k} \mid t_{k}>0\right]}{\partial \tau}+\frac{\partial P\left(t_{k}>0\right)}{\partial \tau} \cdot E\left[t_{k} \mid t_{k}>0\right] .
$$


TABLE 6

Simulated Change in Transfers for Changes in Tax Policy

\begin{tabular}{|c|c|c|}
\hline \multirow[b]{2}{*}{ Tax policy } & \multicolumn{2}{|c|}{$\begin{array}{l}\text { Decrease in transfers } \\
\text { relative to current status (\%) }\end{array}$} \\
\hline & Probability & Amount ${ }^{(a)}$ \\
\hline \$1-million exemption & 0.9 & 12.3 \\
\hline $\begin{array}{l}\$ 1.0 \text {-million exemption; } \\
\text { decrease in rates of } 7.5 \\
\text { percentage points }\end{array}$ & 1.1 & 17.9 \\
\hline No estate tax & 1.6 & 27.8 \\
\hline
\end{tabular}

Sample is singles with wealth $>\$ 600,000$, couples with wealth $>\$ 1.2$ million.

(a) Figure reported is the unconditional change, calculated from the change in the expected value $E\left[t_{k}\right]$ $=P\left(t_{k}>0\right) \cdot E\left[t_{k} \mid t_{k}>0\right]+P\left(t_{k} \leq 0\right) \cdot 0$.

spouse. These results are presented in Table 6 . When the exempt amount is raised to $\$ 1$ million, the probability of making a transfer falls by only 0.9 percent, but the total amount of the expected transfer decreases by 12.3 percent. Thus, while wealthy parents are not likely to stop transferring resources to their children in response to this change in the tax structure, they are likely to reduce the amount they transfer.

The Taxpayer Refund and Relief Act of 1999 calls for a gradual elimination of the estate and gift taxes by the year 2009. The phase-out of the tax begins in 2001 and 2002 with reductions in the top marginal rates to 50 percent. Tax rates (across the board) are then lowered further in each year, beginning in 2003, for a total reduction of 7.5 percentage points by the end of the phase-out period. ${ }^{29}$ These decreases in rates are accompanied by a gradual increase in the exempt amount to $\$ 1$ million. When the estate tax is eliminated entirely in 2009 , there is a corresponding change in the laws governing the capital gains treatment of bequests. Specifically, the step up in basis value that currently exists for assets transferred as bequests will be eliminated for estates of more than $\$ 2$ million bequeathed to a nonspouse heir. 30

There are a number of possible simulations that these changes bring to mind, I focus on two: First, I simulate the expected transfer behavior given the tax environment in the final year before the estate tax is eliminated. In this scenario, the exempt amount is $\$ 1$ million and the mar-

29 This 7.5-percentage-point reduction for the wealthiest comes after the lowering of the top marginal rates to 50 percent.

30 The elimination of the step up in basis is not immediate, but is phased in gradually for estates valued between $\$ 1.3$ million and $\$ 2$ million. The spousal exemption for basis step up is limited to $\$ 3$ million. See United States Congress (1999a, 1999b) for further details. 
ginal rates are reduce by 7.5 percentage points, with the reduction for the top brackets coming after the lowering of rates to 50 percent. This simulation provides an interesting comparison with the one above, wherein the exempt amount is also $\$ 1$ million, but the marginal tax rates remain at their initial levels. Second, I simulate the effect of eliminating all estate taxes.

With the $\$ 1$-million exemption and the lower marginal tax rates, there is a decrease of 1.1 percent in the average probability of making a transfer, and a relatively large fall of 17.9 percent in the amount transferred. Note that the change in the reduction in transfer probabilities and amounts from row 1 of table 6 is due to the lower tax rates faced by those with estates over $\$ 1$ million. Thus, the reduction in rates has only a small effect on the probability of a transfer, but a large effect on the amount given.

Assuming there is no estate tax, the change in the probability of a transfer remains relatively small, equal to 1.6 percent, but the expected amount declines by a large amount, equal to 27.8 percent.

I emphasize that these simulations are based on the assumption that the coefficients on the tax variables estimate the true effects of the tax and are not capturing additional nonlinear effects of wealth. If wealth effects have biased these coefficient estimates, then the actual changes in giving associated with changes in the tax law will be smaller than these figures indicate.

An important goal of proposals to reduce or eliminate the estate tax is to enable donors to transfer more resources to their heirs. The results in Tables 5 and 6 suggest that the short-term effect will be a reduction in inter vivos giving. If the timing of the transfers is important to children, and earlier is preferable to later, then this postponement of parental giving may reduce the child's well-being. It is also unclear how much of the tax savings will be passed along to children. In the absence of an estate tax, the parents' lifetime wealth is greater. Some of this increase in wealth will translate into an increase in the amount bequeathed to children, some will be used to increase the parents' own consumption, and some may be used to increase charitable giving.

The effect on charitable giving is noteworthy. On the one hand, the wealth effect increases charitable gifts, while on the other, eliminating the estate tax eliminates the preferential tax treatment of charitable gifts so that the prices of bequeathing to children and to charities are the same. This increase in the relative price of charitable bequests will decrease the fraction of the estate bequeathed to charitable institutions. Evidence in the literature suggests that the net effect would be a decrease in charitable giving. However, not all research supports this view. Early work by Barthold \& Plotnick (1984) found no relationship between 
the rate of estate tax and charitable bequests. Furthermore, Auten and Joulfaian (1996) estimate that elimination of an estate tax would also reduce inter vivos charitable giving by individuals with children.

\section{THE EXTENT OF GIVING}

Much of the theoretical literature has focused on a comparison of the benefits of making taxable inter vivos gifts relative to taxable bequests. Little attempt has been made to estimate the extent to which wealthy individuals are taking full advantage of the opportunities for tax-free giving. If the wealthy are not using the $\$ 10,000$ annual exclusion, a focus on the merits of giving beyond this level seems unwarranted. The results presented here indicate that individuals do respond to estate and gift taxes by making more and larger inter vivos transfers to children, but they have not addressed the question of whether the wealthy give to the full extent predicted by a tax minimization strategy.

To examine this issue I limit the sample to the subset of wealthy individuals (those with per-person wealth above $\$ 600,000$ ) and calculate the amount that could be given if each spouse (or single parent) gave $\$ 10,000$ to each of his children, grandchildren, and children-in-law. This calculation provides a measure of the ability to reduce the size of the estate in a single year through tax-free familial transfers. ${ }^{31}$ If multiplied by the expected length of life, the total provides the expected amount that could be given to children, free of any transfer taxes, over the remainder of the parent's life.

The potential for yearly giving in this sample is surprisingly large. The average number of children is 3.1, and the average number of grandchildren is $3.4 .^{32}$ Including children-in-law with these lineal descendants results in an average potential number of familial beneficiaries of 9.1. Allowing each spouse in a married couple to make a $\$ 10,000$ gift, the average potential tax-free transfer is $\$ 147,000$ per year. Continued transfers of this magnitude over the parent's expected life yields a total potential for tax-free inter vivos gifts of over $\$ 4$ million on average, far more than the average asset holdings of even this wealthy group. If the number of potential recipients in each year, for each spouse, is limited to the children of the respondent(s), the potential for yearly tax-free giving is $\$ 50,900$, or approximately $\$ 1.9$ million over the lifetimes of these parents.

31 The potential to give in each year can obviously be as large as the donor wishes, since any recipient qualifies for a tax-free gift of $\$ 10,000$. Furthermore, there is no limit on transfers to a single recipient made specifically for schooling or health expenditures.

32 I remind the reader that the initial selection process limited the sample to those with children. 
TABLE 7

Distribution of Gifts Relative to Exempt Amount

\begin{tabular}{|c|c|c|c|c|}
\hline \multirow[b]{3}{*}{ Percentage of sample } & \multicolumn{4}{|c|}{ Potential recipients of $\$ 10,000$ gift } \\
\hline & \multicolumn{2}{|c|}{$\begin{array}{l}\text { Children, children- } \\
\text { in-law, and } \\
\text { grand-children }\end{array}$} & \multicolumn{2}{|c|}{ Children only } \\
\hline & All & Transfer $>0$ & All & Transfer $>0$ \\
\hline Giving greater than potential & 2.4 & 4.0 & 3.8 & 6.3 \\
\hline Giving equal to potential & 0.7 & 1.2 & 2.8 & 4.8 \\
\hline Giving less than potential & 96.9 & 94.7 & 93.4 & 88.9 \\
\hline Number of observations & 424 & 247 & 416 & 252 \\
\hline
\end{tabular}

Potential is equal to $\$ 10,000$ per recipient.

Sample is singles with wealth $>\$ 600,000$, couples with wealth $>1.2$ million.

Sample sizes differ across columns because of missing information on grandchildren.

How close to these figures do parents come? Are there many who are giving above this limit as would be predicted by the intricacies of the tax code? Table 7 shows the distribution of total giving relative to these tax limits. Only 3.1 percent $(2.4+0.7)$ of those with taxable levels of wealth gave an amount greater than or equal to this potential, while 96.9 percent gave less. Conditional on a positive transfer being made, 5.2 percent gave an amount at or beyond the limit. If the potential to transfer tax-free is measured with respect to children only, the proportion transferring an amount at least equal to the potential is 6.6 percent overall and 11.1 percent among the givers. ${ }^{33}$

The potential tax savings lost by this relatively low level of giving is substantial. Poterba (2000a) estimates that planned giving in each year up to the annual exclusion could reduce taxable wealth by 23 percent. Based on his calculations, this level of giving implies a yearly flow of inter vivos transfers of $\$ 235$ billion. However, estimates made by Poterba and by others (Gale and Scholz, 1994) indicate that the amount actually transferred is less than one-quarter as much, implying a substantial shortfall in giving. Using the same survey, Page (1997) calculates that if parents maximized their tax-free giving, no one in his sample would be faced with paying estate taxes.

Additional evidence of this phenomenon comes from McGarry (2000). Estimates in that paper show that by maximizing tax-free giving to chil-

33 If I ignore the potential for married couples to each make a transfer of $\$ 10,000$, the fraction of the sample transferring an amount greater than or equal to $\$ 10,000$ per child remains small at 9.4 percent. 
dren, children-in-law, and grandchildren, parents in the HRS and AHEAD could reduce the total tax bill by 72 percent relative to the amount owed with no giving. Projecting the actual giving observed in the data over the remainder of the respondents' expected lives yields an expected reduction in the tax bill of just 20 percent.

Given the attention paid to estate planning in the popular press and by the public, the frequency with which the wealthy elderly fail to exploit this simple means of decreasing the size of their estates is surprising. There have been several explanations put forth for this lower than expected level of giving, many of which are noted in Poterba (2000a). First, it might be that elderly parents are risk-averse and are concerned about outliving their assets. They do not want to give away too much and end up with insufficient wealth should they live a long life. On a related point, these parents may fear that substantial medical expenses or the need for nursing-home care could deplete their resources. Poterba suggests further that these wealthy elderly may believe they are more capable investors than their children and seek to maintain control of dynastic wealth for as long as possible. Likewise, they may receive utility from holding wealth or from the respect or power it confers. Alternatively, those who do not take advantage of tax-free giving could simply misunderstand the full implications of the tax law, or could anticipate changes in the law that would negate the need for inter vivos giving.

Although none of these explanations can be tested directly, there are some correlates that one can use to investigate their likely relevance. In Table 8 I examine differences in observable characteristics among those in the wealthy subsample who make transfers equal to at least $\$ 10,000$ per child ("limit-givers") and those who do not ("non-limit-givers"). Given the small sample sizes, useful multivariate analyses are not possible, and these simple differences in means across groups should be interpreted with caution.

Consider first the suggestion that those who are transferring less than the potential tax-free amount are doing so because they fear outliving their assets. Table 8 shows that the limit-givers are somewhat older and report a lower subjective survival probability than their counterparts, consistent with their greater willingness to spend down assets. ${ }^{34}$

Differences in insurance status support the notion that the threat of future medical expenses might also be responsible for the observed behavior. Those making large transfers are more likely to have private

${ }^{34}$ The subjective survival measures are responses to the questions: ". . what is the probability you will live to age 75?" (for the HRS) and the probability of living approximately 10 more years (AHEAD). Responses of spouses are averaged together for both this measure and for age. 
TABLE 8

Differences by Transfer Behavior for Those with Taxable Estates

\begin{tabular}{|c|c|c|c|c|}
\hline & \multicolumn{4}{|c|}{ Gave at least $\$ 10,000$ per child } \\
\hline & \multicolumn{2}{|c|}{ Yes } & \multicolumn{2}{|c|}{ No } \\
\hline & Mean & Std. err. & Mean & Std. err. \\
\hline Age & 64.4 & 2.1 & 61.3 & 0.5 \\
\hline $\begin{array}{l}\text { Probability of surviving to } 75 \\
\text { (HRS) }\end{array}$ & 0.65 & 0.05 & 0.71 & 0.01 \\
\hline $\begin{array}{l}\text { Probability of surviving } 10 \\
\text { years (AHEAD)* }\end{array}$ & 0.40 & 0.10 & 0.53 & 0.03 \\
\hline Either spouse in poor health & 0.15 & 0.07 & 0.07 & 0.01 \\
\hline $\begin{array}{l}\text { Private health insurance* } \\
\text { (those with Medicare) }\end{array}$ & 0.70 & 0.11 & 0.59 & 0.04 \\
\hline Long-term care insurance* & 0.43 & 0.15 & 0.25 & 0.05 \\
\hline $\begin{array}{l}\text { Long-term care insurance } \\
(\mathrm{HRS})^{+*}\end{array}$ & 0.40 & 0.24 & 0.07 & 0.03 \\
\hline Number of children & 1.94 & 0.19 & 3.19 & 0.09 \\
\hline $\begin{array}{l}\text { Average schooling of } \\
\text { children }\end{array}$ & 15.5 & 0.32 & 14.6 & 0.09 \\
\hline Average income of children & 51,355 & 5,843 & 41,485 & 958 \\
\hline $\begin{array}{l}\text { Fraction of children with } \\
\text { more schooling than } \\
\text { parents }\end{array}$ & 0.32 & 0.09 & 0.35 & 0.02 \\
\hline $\begin{array}{l}\text { Fraction of children finan- } \\
\text { cially better off than } \\
\text { parents }\end{array}$ & 0.14 & 0.08 & 0.25 & 0.04 \\
\hline Have a financial advisor ${ }^{*}$ & 0.29 & 0.13 & 0.48 & 0.05 \\
\hline $\begin{array}{l}\text { Transferred } \$ 5,000 \text { or more } \\
\text { in past } 10 \text { years }\end{array}$ & 1.0 & 0.0 & 0.51 & 0.05 \\
\hline \multicolumn{5}{|l|}{$\begin{array}{l}\text { Importance of leaving an } \\
\text { Inheritance }{ }^{* *} \text { : }\end{array}$} \\
\hline $\begin{array}{l}\text { Percent stating very } \\
\text { important }\end{array}$ & 60.0 & & 35.1 & \\
\hline $\begin{array}{l}\text { Percent stating somewhat } \\
\text { important }\end{array}$ & 33.3 & & 47.0 & \\
\hline $\begin{array}{l}\text { Percent stating not } \\
\text { important }\end{array}$ & 6.7 & & 17.8 & \\
\hline $\begin{array}{l}\text { Number of obs. when in } \\
\text { both surveys }\end{array}$ & & 28 & & 396 \\
\hline $\begin{array}{l}\text { Number of obs. when in } \\
\text { AHEAD only }\end{array}$ & & 13 & & 10 \\
\hline
\end{tabular}

Variables with * are available for AHEAD families only; those with **, for HRS only. The number of observations therefore differs across variables. 
health insurance to supplement Medicare (among those enrolled in Medicare), and more likely to have long-term care insurance, both of which reduce the probability of catastrophic medical bills, allowing individuals to more readily reduce assets. This explanation takes insurance holdings as given. If instead if one views insurance holdings as an indicator of risk aversion, then these differences suggest that the limit-givers are more risk-averse. By purchasing insurance they have eliminated one precautionary motive to save, but one would expect them to remain hesitant to dispose of assets due to other uncertainties, contrary to what would be predicted by their giving behavior.

It is obviously not possible using survey data to measure a child's ability to invest wisely. However, it is worth noting that both the average schooling and average income of children is marginally higher among the limit-givers. Thus, on an absolute level, the children of limit-givers are better off than those of non-limit-givers. Interestingly, the reverse is true if one measures financial status relative to their parents. On average, just 32 percent of the children of limit-givers have more schooling than their parents, and only 14 percent are better off financially. For the non-limit-givers these figures are 35 and 25 percent. ${ }^{35}$ These differences in the relative economic well-being of children are consistent with transfers being made, in part, out of a desire to reduce inequalities within the family, rather than for tax considerations alone.

It is unlikely that the wealthiest in the sample are completely unaware of the tax consequences of their behavior. Having amassed a sizable estate, one would imagine that they have a good deal of financial knowledge, as well as access to expert opinions. In fact, while 29 percent of the limit-givers have a financial planner, 48 percent of the non-limit-givers do, suggesting that the non-limit-givers are not lacking information.

Finally, consider the possibility that not all parents desire to increase transfers to their children. They may believe that even net of taxes, the amount bequeathed will be large, and that additional transfers are better spent by the government or charitable institutions. While attributing differences in behavior to differences in tastes certainly begs the question of the origin of these tastes, the empirical evidence indicates that such differences are large. Among AHEAD respondents, all of the limitgivers transferred $\$ 5000$ or more to a child in the past 10 years, compared to just one-half of the non-limit-givers. This information is not obtained

${ }_{35}$ The variable measuring relative financial status is the response to a question in $\mathrm{AHEAD}$ that asks parents to report if the child's "financial situation (is) better, about the same, or worse than" theirs. 
in the HRS, but parents in that survey were asked about their views on bequests. The survey asked whether leaving an inheritance was, "very important, somewhat important, or not important." The distribution of responses to this question also demonstrates a strong difference in views about giving. Sixty percent of the limit-givers thought it was very important to leave an inheritance, compared to just 35 percent of the non-limitgivers. At the other tail, less than 7 percent of the limit-givers viewed leaving an inheritance as unimportant, while 18 percent of the non-limitgivers did. These differences in past giving and in the importance of leaving an inheritance could be an indicator of substantial heterogeneity in the desire to give to children.

\section{CONCLUSIONS}

The decision to make inter vivos transfers is complex. Such transfers depend strongly on parental income and wealth and on the resources of the children (McGarry and Schoeni, 1995, 1997). Transfers also depend on the likely tax status of the estate (Poterba, 2000a, b; McGarry, 2000) and, as demonstrated here, on the marginal tax rate itself. Transfers are more common among those with taxable wealth and are made in larger amounts. Furthermore, both the probability and expected amount of transfers vary positively with the marginal tax rate. Changes in estate taxes, operating through changes in the lifetime exemption and in the tax rates themselves, have a strong effect on the transfer behavior of the wealthy. In simulations, eliminating the estate tax results in a decrease of nearly 30 percent in expected transfers to children among those initially subject to tax.

While the literature has focused on the role of taxable inter vivos transfers as a mechanism to reduce estate and gift taxes, the evidence presented here suggests that not only do the wealthy fail to make inter vivos gifts above the tax-free limits, but they also forgo many opportunities to reduce the tax owed by the estate by costlessly transferring $\$ 10,000$ per year to children; 90 percent of wealthy parents transfer less than this amount. Although several explanations have been offered for this lack of giving, we are only beginning to assess their validity, and certainly additional investigation is needed.

Finally, inter vivos transfers are also relatively frequent among those unlikely to face estate taxation. In the sample used in this paper, 30 percent of parents with wealth below the taxable limits made transfers to their children in the past year, suggesting that there are important motives for transferring resources beyond those due to tax planning. Thus, while one should conclude that estate and gift taxes likely play an impor- 
tant role in altering the transfer behavior of the wealthy, the decision process is sufficiently complex that numerous other factors also affect this behavior.

\section{APPENDIX}

The means and standard errors of the variables used in the analysis are given in Table 9.

TABLE 9

Means of Variables Used in Analysis

$\begin{array}{lll}\text { Mean } & \text { Std. err. }\end{array}$

Financial variables

Bequeathable wealth

261,530

4,550

Log of positive values

11.05

0.027

Income (respondent and spouse)

32,929

423

Log of positive values

9.62

0.019

Fraction of wealth in home (overall)

0.148

0.004

Fraction of wealth in business (overall)

0.058

0.024

Fraction of wealth in farm (overall)

0.019

0.001

Fraction of wealth in stock (overall)

0.055

0.012

Marginal tax rates

Full sample

0.02

0.001

Conditional on positive tax

0.41

0.002

Demographic variables

Life expectancy

29.2

0.15

Married

0.58

0.005

Nonwhite

0.16

0.003

Number of children

Average age of children

3.29

0.012

Average income of children

37.4

0.11

37,040

195

Transfer behavior

Transfer to at least one child

0.32

0.004

Total amount of transfers (over positive

5,608 values)

Number of observations ${ }^{(a)}$

11,754

(a) The number of observations differs for some variables due to missing values. 


\section{REFERENCES}

Auten, Gerald, and David Joulfaian (1996). "Charitable Contributions and Intergenerational Transfers." Journal of Public Economics 59:55-68.

Barthold, Thomas and Robert Plotnick (1984). "Estate Taxation and other Determinants of Charitable Bequests," National Tax Joumal 37 (2): 225-237.

Boskin, Michael J. (1976). "Estate Taxation and Charitable Bequests." Journal of Public Economics 5:27-56.

Cooper, George (1976). A Voluntary Tax? Washington: The Brookings Institute.

Cox, Donald (1990). "Intergenerational Transfers and Liquidity Constraints." Quarterly Journal of Economics 95(no. 3):509-546.

Eller, Martha Britton (1996). "Federal Taxation of Wealth Transfers." Statistics of Income Bulletin: Winter, 8-23. Washington: Internal Revenue Service.

Feldstein, Martin, and Charles Clotfelter (1976). "Tax Incentives and Charitable Giving in the United States." Journal of Public Economics 5:1-26.

Gale, William, and Maria Perozek (1999). "Do Estate Taxes Reduce Savings?" The Brookings Institute. Mimeograph.

Gale, William, and John Karl Scholz (1994). "Intergenerational Transfers and the Accumulation of Wealth." The Journal of Economic Perspectives 8(no. 4):145160.

Internal Revenue Service (1997). Introduction to Estate and Gift Taxes. Department of the Treasury. Publication 950. June.

- (1999). "Instructions for Form 709." January.

Joulfaian, David (1991). "Charitable Bequests and Estate Taxes." National Tax Journal 44:169-180.

(1998). "The Federal Estate and Gift Tax: Description, Profile of Taxpayers and Economic Consequences." U.S. Department of the Treasury. OTA Paper 80.

_ (1999). "To Gift or to Bequest: Do the Wealthy Equalize True Estate and Gift Tax Rates?" U.S. Department of the Treasury. June. Mimeograph.

Joulfaian, David, and Mark Wilhelm (1994). "Inheritance and Labor Supply." Journal of Human Resources 29:1205-1234.

McGarry, Kathleen (1999). "Inter Vivos Transfers and Intended Bequests." Journal of Public Economics 73:321-351.

(2000). "The Cost of Equality: Unequal Bequests and Tax Avoidance." Forthcoming in Journal of Public Economics.

McGarry, Kathleen, and Robert Schoeni (1995). "Transfer Behavior in the Health and Retirement Study: Measurements and the Redistribution of Resources within the Family." Journal of Human Resources 30:s184-s226.

- (1997). "Transfer Behavior within the Family: Results from the Asset and Health Dynamics Survey." Journals of Gerontology 52B:82-92.

Page, Benjamin (1997). "Bequest Taxes, Inter Vivos Gifts, and the Bequest Motive." Congressional Budget Office. Mimeograph.

Poterba, James (2000a). "The Estate Tax and After-Tax Investment Returns." Forthcoming in Does Atlas Shrug? The Economic Consequences of Taxing the Rich, Joel Slemrod (Ed.). Cambridge, MA: Harvard University Press.

(2000b). "Estate and Gift Taxes and Incentives for Inter Vivos Giving in the United States." Forthcoming in Journal of Public Economics. 
United States Congress (1999a). Taxpayer Refund and Relief Act of 1999. Enrolled Bill H.R.2488.ENR.

(1999b). Taxpayer Refund and Relief Act of 1999, Conference Report to Accompany H.R. 2488. Report 106-289.

United States Department of Health and Human Services (1996). Vital Statistics of the United States, 1992. Volume II, Mortality. Hyattsville, MD. 
